\title{
Spatial variability and trends of the rain intensity over Greece
}

\author{
H. D. Kambezidis ${ }^{1}$, I. K. Larissi ${ }^{2}$, P. T. Nastos ${ }^{3}$, and A. G. Paliatsos ${ }^{4}$ \\ ${ }^{1}$ Atmospheric Research Team, Institute of Environmental Research and Sustainable Development, National Observatory of \\ Athens, P.O. Box 20048, 11810 Athens, Greece \\ ${ }^{2}$ Laboratory of Environmental Technology, Technological Education Institute of Piraeus, 12244 Athens, Greece \\ ${ }^{3}$ Laboratory of Climatology and Atmospheric Environment, Faculty of Geology and Geoenvironment, University of Athens, \\ Panepistimiopolis, 15784 Athens, Greece \\ ${ }^{4}$ General Department of Mathematics, Technological Education Institute of Piraeus, 12244 Athens, Greece
}

Received: 2 March 2010 - Revised: 6 April 2010 - Accepted: 14 June 2010 - Published: 9 July 2010

\begin{abstract}
In this study, the spatial and temporal variability of the mean annual rain intensity in Greece are examined during a 41-year period (1962-2002). The meteorological datasets concern monthly rain amounts $(\mathrm{mm})$ and the respective monthly durations (h) recorded at thirty two meteorological stations of the Hellenic National Meteorological Service, which are uniformly distributed on Greek territory, in order to calculate the mean monthly rain intensity. All the rain time series used in the analysis were tested by the application of the short-cut Bartlett test of homogeneity. The spatial distribution of the mean annual rain intensity is studied using the Kriging interpolation method, while the temporal variability, concerning the mean annual rain intensity trends along with their significance (Mann-Kendall test), is analysed.

The findings of the analysis show that statistically significant negative trends (95\% confidence level) appear mainly in the west sub-regions of Greece, while statistically significant positive trends (95\% confidence level) appear in the wider area of Athens and the complex of Cyclades Islands. Further analysis concerning the seasonal rain intensity is needed, because there are different seasonal patterns, taking into account that, convective rain in Greece occurs mainly within the summer season.
\end{abstract}

\section{Introduction}

Rain variability in space and time is one of the most relevant characteristics of Mediterranean climate that is associated with economic, social and ecological implications. Extreme rain events have significant environmental consequences that cause considerable damages in urban as well as in rural areas.

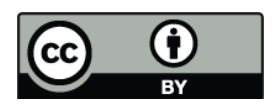

Correspondence to: P. T. Nastos

(nastos@geol.uoa.gr)
The frequency of heavy precipitation events has increased over most land areas, consistent with warming and observed increases of atmospheric water vapour. Besides, it is very likely that future trends in the frequency of heavy precipitation events (or proportion of total rainfall from heavy falls) will happen over most areas, based on projections for the $21^{s t}$ century using SRES scenarios (IPCC, 2007).

The daily precipitation time series indicate significant positive trends for the United States (Karl et al., 1995; Karl and Knight, 1998), Japan (Iwashima and Yamamoto, 1993) and tropical Australia (Suppiah and Hennessey, 1998), while statistically insignificant trends are observed in other areas (Yu and Neil, 1991; Karl et al., 1995). Concerning Greece, relative research with respect to precipitation variability and distribution of precipitation frequency (Katsoulis and Kambezidis, 1989; Nastos 1993; Metaxas et al., 1999; Nastos et al., 2002; Maheras and Anagnostopoulou, 2003; Paliatsos et al., 2005; Feidas et al., 2007; Nastos and Zerefos, 2009), extreme events and rain intensity (Kostopoulou and Jones, 2005; Nastos and Zerefos, 2007, 2008; Nastos, 2008) has been carried out.

The study of rain intensity trends is a good tool for policy makers, in order to estimate, among other factors, the erosion and the desertification that appear as a consequence of the climatic change in the eastern Mediterranean Sea.

The objective of this study is to examine the spatial and temporal distribution of the mean annual rain intensity in Greece giving evidence of the incidence of extreme rain events in specific regions of Greece.

\section{Data and analysis}

Rain variability in space and time is one of the most relevant characteristics of the Mediterranean climate that is associated with economic, social and ecological implications. Extreme

Published by Copernicus Publications on behalf of the European Geosciences Union. 


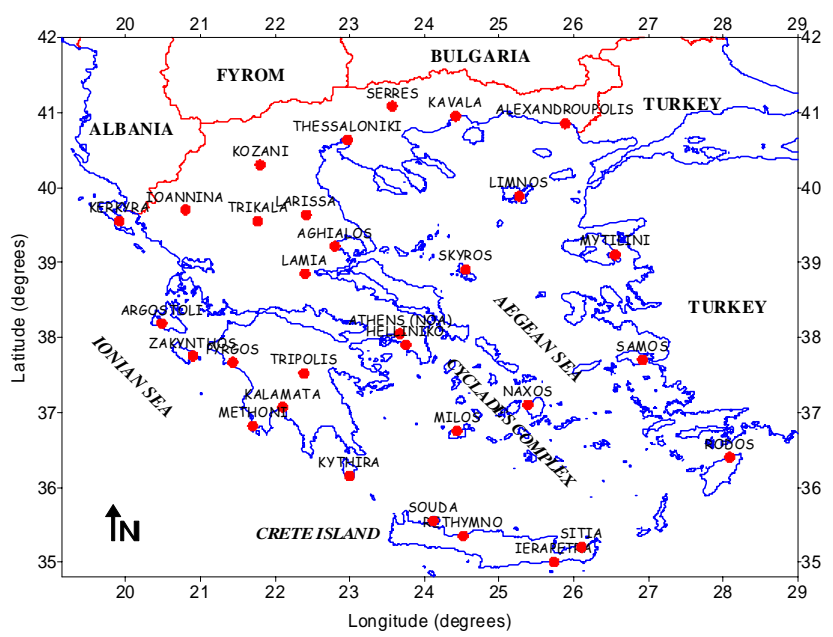

Fig. 1. Meteorological stations from the HNMS network used in the analysis. An even geographical distribution of the stations in the Greek territory is espied.

rain events have significant environmental consequences that cause considerable damage in urban as well as in rural areas.

In this study, the spatial and temporal variability of the mean annual rain intensity in Greece is examined, during the period 1962-2002. The available meteorological data used in this study concern monthly rain amounts $(\mathrm{mm})$ and the respective monthly durations (h), in order to calculate the mean monthly rain intensity. The monthly data were acquired from thirty two meteorological stations belonging to the Hellenic National Meteorological Service (HNMS); all these time series were tested for homogeneity by applying the short-cut Bartlett test. The geographical distribution of the meteorological stations is depicted in Fig. 1.

The spatial distribution of the mean annual rain intensity (RI) is studied using the Kriging interpolation method. Besides, the temporal variability concerning the mean annual $\mathrm{RI}$ trends along with their significance is analysed through the Mann-Kendall test (Mitchell et al,, 1966).

\section{Spatial variability of the mean annual rain intensity}

According to the performed analysis, high RI patterns appear at the western sub-regions $(\sim 4.0 \mathrm{~mm} / \mathrm{h})$ followed by the south-eastern sub-regions $(\sim 2.6 \mathrm{~mm} / \mathrm{h})$ of Greece, while low RI $(\sim 1.1 \mathrm{~mm} / \mathrm{h})$ dominate at the majority of the Aegean Sea along with the coastal areas of the western Aegean Sea. The coastal areas and the islands of the north-eastern Aegean Sea depict relatively higher RI $(\sim 1.7 \mathrm{~mm} / \mathrm{h})$ (Fig. 2$)$. In this point, it should be remarked that, the rain intensity values represent the mean pattern and they are far away from the intensities of isolated convective rain events, which can reach dozens of $\mathrm{mm} / \mathrm{h}$. As it has been mentioned previously, the monthly rain total is divided by the respective monthly dura-

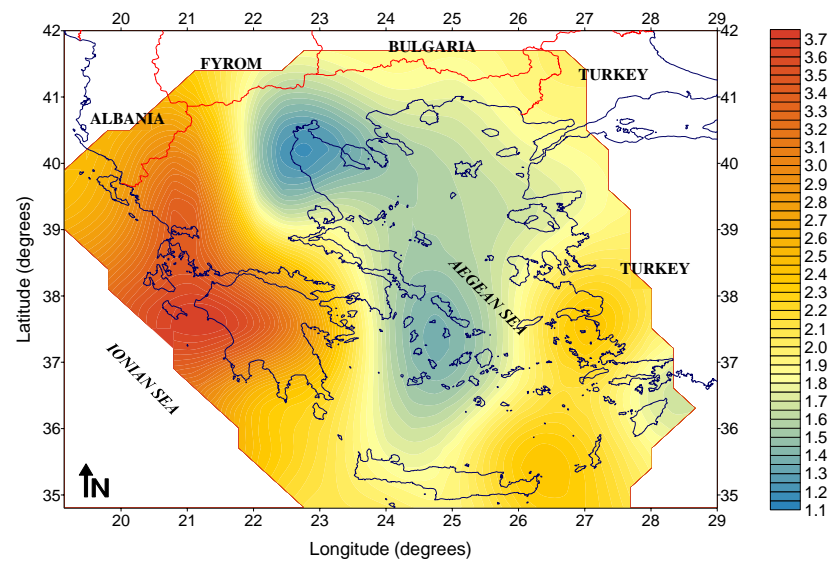

Fig. 2. Spatial distribution of the mean annual RI $(\mathrm{mm} / \mathrm{h})$, in Greece, during the period 1962-2002.

tion having as a result the mean monthly rain intensity, and thereafter the mean annual and seasonal values. This is a limitation of the study, with respect to extreme events, which cannot be well expressed.

The high mean annual RI pattern is mainly attributed to the summer thermal convective thunderstorms $(\sim 6.0 \mathrm{~mm} / \mathrm{h})$ appearing along the long mountainous range of Pindos at the west of Greece and at the central mountainous Peloponnese and secondly to the mean winter RI pattern $(\sim 3.0 \mathrm{~mm} / \mathrm{h})$. The winter precipitation is also of high intensity especially in west and north-west Greece, with the appearance of thunderstorms. These precipitations are mainly attributed to the cold fronts or the unstable air masses within the warm section of the depressions (Nastos et al., 2002).

\section{Temporal variability of the mean annual rain inten- sity}

Our findings show that, statistically significant (95\% confidence level) positive trends of RI appear in the wider area of Athens $(+0.43 \mathrm{~mm} / \mathrm{h}$ per decade $)$, Crete Island (Rethymno: $0.34 \mathrm{~mm} / \mathrm{h}$ per decade), Cyclades complex (Naxos: $+0.22 \mathrm{~mm} / \mathrm{h}$ per decade) and north-eastern subregions (Alexandroupolis: $+0.19 \mathrm{~mm} / \mathrm{h}$ per decade) (Fig. 3).

A physical explanation of the positive RI trends in the wider area of Athens is the urban heat island (UHI), which is responsible for heavy storms of convective nature (Nastos and Zerefos, 2007). More specifically, on seasonal basis, the rain intensity is higher in summer and fall than in spring and winter, indicative of the relatively higher thunderstorm activity during summer and fall. At this point, it must be signified that, during the recent period (1990-2004) the maximum rain intensity values exceeding $30 \mathrm{~mm} / \mathrm{h}$ appear only within the dry period of the year (April-September) (Philandras et al., 2010). 


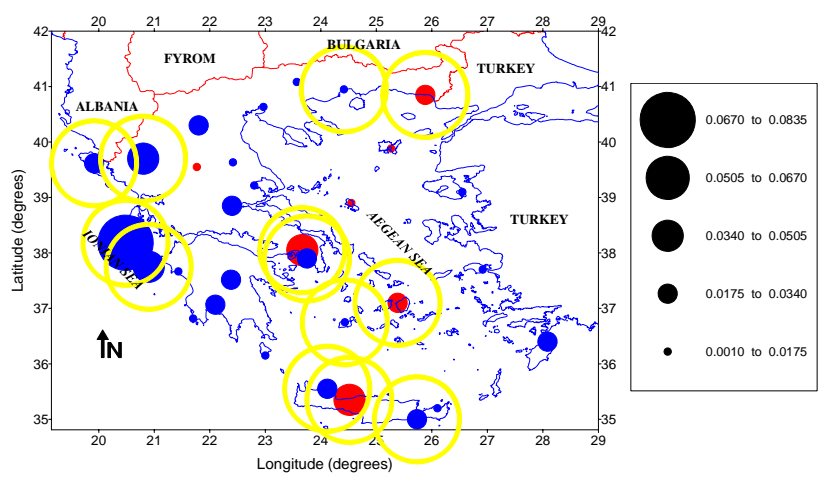

Fig. 3. Spatial distribution of the mean annual RI $(\mathrm{mm} / \mathrm{h})$ trends over Greece, during the period 1962-2002. The red and blue proportional circles indicate positive and negative trends, respectively; the yellow rings show statistical significance of the trends at the $95 \%$ confidence level.

Statistically significant (95\% confidence level) negative trends dominate all over the rest of the country and especially the western continental (Ioannina: $-0.38 \mathrm{~mm} / \mathrm{h}$ per decade) and coastal sub-regions and islands (Argostoli: $-0.84 \mathrm{~mm} / \mathrm{h}$ per decade). These negative trends are more pronounced during summer than winter. Figure 4 depicts the annual RI time series for selected stations, representing the sub-regions of Greece, along with 9-year points moving average and linear trends, during the period 1962-2002.

These findings are in agreement with the findings of Nastos (2008), who studied the spatial and temporal pattern of the Simple Daily Intensity Index (SDII, $\mathrm{mm} / \mathrm{day}$ ) in Greece. It is worthy to mention that, the annual precipitation follows a higher significant $(95 \%$ C.L.) negative trend than the number of rain days, approximately all over Greece. This results in negative trends in SDII, which are higher in western and northern mountainous regions. Besides, Brunetti et al. (2000) provided evidence that in northern Italy, the number of rainy days has a stronger and more significant negative trend than the corresponding precipitation amount, both on a yearly basis and in all of the seasons; as a consequence, precipitation intensity $(\mathrm{mm} /$ day) has a positive trend.

Additionally, in several regions such as South Africa, Siberia, the Eastern Mediterranean Sea, central Mexico, and northern Japan, rainy days are becoming less frequent and an increase only in heavy precipitation is observed while total precipitation and/or the frequency of days with an appreciable amount of precipitation are not changing and/or are decreasing (Easterling et al., 2000; Alpert et al., 2002; Fauchereau et al., 2003; Groisman et al., 2005). Besides, Zerefos et al. (2010), found negative trends in precipitation during the rainy season (October to April) in Greece. These negative trends are estimated to be about $20 \mathrm{~mm}$ (or 2.3\%) per decade for western Greece since 1900, to about $3.3 \mathrm{~mm}$ (or $0.7 \%$ ) per decade for eastern Greece since 1900, and to

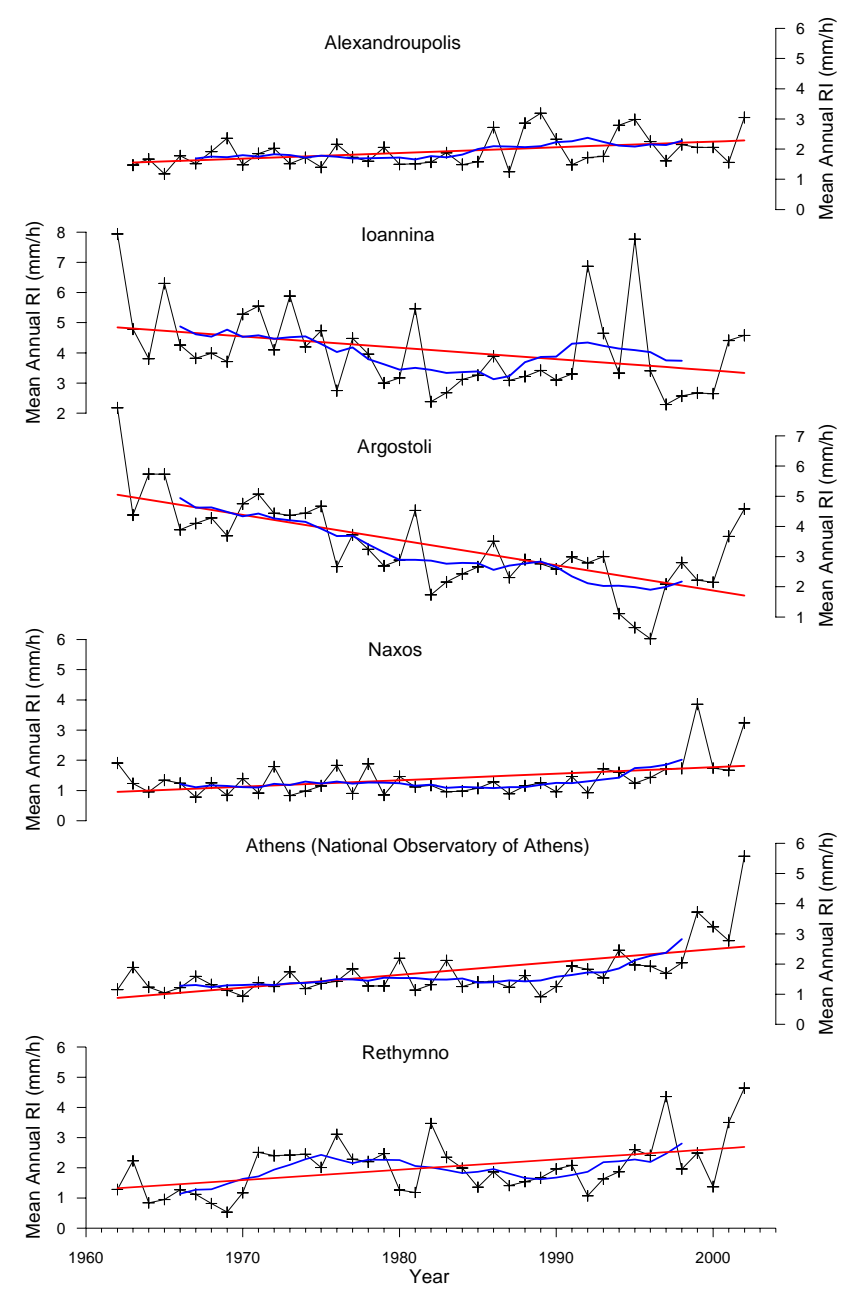

Fig. 4. Time series of the mean annual RI ( $\mathrm{mm} / \mathrm{h})$, along with 9 -year points moving average (blue line) and trend (red line), for selected stations in Greece, during the period 1962-2002.

about $9.5 \mathrm{~mm}$ (or $2 \%$ ) per decade for the eastern Aegean since 1950.

The negative trends in the rain intensity are associated with the negative trends in precipitation especially at western Greece, which is on the lee side of the mountains. This could be attributed to the influence of the North Atlantic Oscillation (NAO) on precipitation data. The inter-annual variability of precipitation is significantly correlated both interannually and in the long term with the variability of NAO (correlation of -0.38 , confidence level $>99 \%, 116$ Nobs). The respective correlation for eastern Greece is estimated to about -0.21 (confidence level 95\%, 118 Nobs) and for the eastern Aegean Sea to about -0.19 (confidence level 90\%, 94 Nobs) (Zerefos et al., 2010). 


\section{Conclusions}

The main conclusions of the performed analysis could be summarized in the following:

- The mean annual rain intensity pattern (period 19622002) showed that high values are depicted at the western sub-regions followed by those in the south-eastern sub-regions of Greece, while low values appeared in the majority of the Aegean Sea along with the coastal areas of the western Aegean Sea.

- The trend analysis revealed that statistically significant (95\% confidence level) positive trends of the mean annual rain intensity appear in the wider area of Athens (very likely attributed to an enhanced UHI effect), the northern coastal areas of Crete Island, the Cyclades complex and the north-eastern sub-regions of Greece. On the other hand, statistically significant (95\% confidence level) negative trends appear in the rest of the country and especially the western continental and coastal sub-regions and islands.

A limitation of this work is that, studying the rain intensity on an annual basis, the different seasonal patterns are not revealed, taking into account that convective rain in Greece happens mainly within the summer season. Further analysis, which is in progress by the authors, is needed in order to interpret better the temporal variability of the rain intensity in Greece.

Edited by: R. Deidda

Reviewed by: one anonymous referee

\section{References}

Alpert, P., Ben-Gai, T., Baharad, A., Benjamini, Y., Yekutieli, D., Colacino, M., Diodato, L., Homar, V., Ramis, C., Romero, R., Michaelides, S., and Manes, A.: The paradoxical increase of Mediterranean extreme daily rainfall in spite of decrease in total values, Geophys. Res. Lett., 29(11), 1536, doi:10.1029/2001GL013554, 2002.

Brunetti, M., Buffoni, L., Maugeri, M., and Nanni, T.: Precipitation intensity trends in northern Italy, Int. J. Climatol., 20(9), 10171031, 2000.

Easterling, D. R., Evans, J. L., Groisman, P. Ya., Karl, T. R., Kunkel, K. E., and Ambenje, P.: (2000) Observed variability and trends in extreme climate events: A brief review, Bull. Amer. Meteorol. Soc., 81, 417-425, 2000.

Fauchereau, N., Trzaska, S., Rouault, M., and Richard, Y.: Rainfall variavility and changes in Southern Africa during the 20th century in the global warming context, Natural Hazards, 29, 139$154,2003$.

Feidas, H., Noulopoulou, N., Makrogiannis, T., and Bora-Senta, E.: Trend analysis of precipitation time series in Greece and their relationship with circulation using surface and satellite data: 19552001, Theor. Appl. Climatol., 87, 155-177, 2007.
Groisman, P. Ya., Knight, R. W., Easterling, D. R., Karl, T. R., and Hegerl, G. C.: Trends in intense precipitation in the climate record, J. Climate, 18(9), 1326-1350, 2005.

IPCC: The Physical Science Basis. Contribution of Working Group 1 to the Fourth IPCC Assessment Report, Chapter 11 Regional Climate Projections, 2007.

Iwashima, T. and Yamamoto, R.: A statistical analysis of the extreme events: long-term trend of heavy daily precipitation, J. Meteorol. Soc. Japan, 71, 637-640, 1993.

Karl, T. R. and Knight, R. W.: Secular trends of precipitation amount frequency and intensity in the United States, Bull. Amer. Meteorol. Soc., 79, 231-241, 1998.

Karl, T. R., Knight, R. W., and Plummer, N.: Trends in highfrequency climate variability in the twentieth century, Nature, 377, 217-220, 1995.

Katsoulis, B. D. and Kambezidis, H. D.: Analysis of the long-term precipitation series at Athens, Greece, Clim. Change, 14, 263290, 1989.

Kostopoulou, E. and Jones, P. D.: Assessment of climate extremes in the Eastern Mediterranean, Meteorol. Atmos. Phys., 89, 69$85,2005$.

Maheras, P. and Anagnostopoulou, C.: Circulation types and their influence on the international variability and precipitation changes in Greece, in: Mediterranean climate, Variability and trends, edited by: Bolle, H. J., Spinger, Berlin, Germany, 215239, 2003.

Metaxas, D. A., Philandras, C. M., Nastos, P. T., and Repapis, C. C.: Variabiility of precipitation pattern in Greece during the year, Fresen. Environ. Bull., 8, 1-6, 1999.

Mitchell, J. M. Dzerdzeevskü, B., Flohn, H., Hofmeyr, W. L., Lamb, H. H., Rao, K. N., and Wallén, C. C.: Climatic Change, WMO Technical Note 79, WMO No. 195, TP-100, World Meteorological Organization, Geneva, p. 79, 1966.

Nastos, P. T.: Changements de la pluviosite en region Hellenique pendant la periode 1858-1992. Proceedings of the 6th Colloque International de Climatologie, 6, 183-190, 1993.

Nastos, P. T.: Spatial and temporal variability of the rain intensity in Greece. Proceedings of the 8th Hydrogeological International Congress of Greece, 651-660, 2008.

Nastos, P. T., Philandras, C. M., and Repapis, C. C.: Application of canonical analysis to air temperature and precipitation regimes over Greece, Fresen. Environ. Bull., 11, 488-493, 2002.

Nastos, P. T. and Zerefos, C. S.: On extreme daily precipitation totals at Athens, Greece, Adv. Geosci., 10, 1-8, doi:10.5194/adgeo-10-59-2007, 2007.

Nastos, P. T. and Zerefos, C. S.: Decadal changes in extreme daily precipitation in Greece, Adv. Geosci., 16, 55-62, doi:10.5194/adgeo-16-55-2008, 2008.

Nastos, P. T. and Zerefos, C. S.: Spatial and temporal variability of consecutive dry and wet days in Greece, Atmos. Res., 94, 616628, 2009.

Paliatsos, A. G., Nastos, P. T., Tzavelas, G., and Panagiotakos, D. B.: Characteristics of precipitation in urban Athens area, from 1891 to 2000, Fresen. Environ. Bull., 14, 422-428, 2005.

Philandras, C. M., Nastos, P. T., Paliatsos, A. G., and Repapis, C. C.: Study of the rain intensity in Athens and Thessaloniki, Greece, Adv. Geosci., 23, 37-45, doi:10.5194/adgeo-23-37-2010, 2010. 
Suppiah, R. and Hennessy, K. J.: Trends in total rainfall events and number of dry events in Australia. 1910-1990, Int. J. Climatol., 18, 1141-1164, 1998.

Yu, B. and Neil, D. T.: Global warming and regional rainfall: the difference between average and high intensity rainfalls, Int. J. Climatol., 11, 653-661, 1991.
Zerefos, C. S., Nastos, P. T., Founda, D., Eleftheratos, K., Philandras, C. M., Xoplaki, E., Lionello, P., et al.: Long-term changes in hyetal characteristics along storm tracks in the Mediterranean with NAO, Geophys. Res. Abstracts, 12, EGU2010-6719-2, 2010. 